\title{
Østrogentilskudd og forskningsparadigmer
}

\author{
Oppfatningen at postmenopausal hormonterapi beskytter mot koronar hjertesykdom ble i 2002 snudd \\ på hodet av nye forskningsresultater. Slik behandling gir økt - ikke mindre - risiko for hjertesykdom. \\ Hvordan kunne dette skje?
}

\section{Anders Erik Astrup Dahm \\ aeadahm@gmail.com}

I sin bok The structure of scientifc revolutions fra 1962 hevdet vitenskapsteoretikeren Thomas Kuhn at forskning hovedsakelig skjer innenfor et forskningsparadigme der alle resultater fortolkes i lys av dette funn som ikke passer inn i paradigmet kalte han anomalier (1). Dersom det oppstår for mange anomalier, vil det skje en omveltning (revolusjon) der det gamle paradigmet blir forlatt og erstattet av et nytt der «anomaliene» passer inn. Deretter kommer en ny forskningsperiode der man fortolker alle funn i lys av det nye paradigmet.

Kuhn beskriver også hvordan mange forskere har bekjempet nye fremvoksende paradigmer og forsvart de gamle (1). Også innen medisinen er det mange eksempler på slike paradigmeskifter.

\section{$\emptyset$ strogener og hjertesykdom}

I 2002 publiserte Rossouw og medarbeidere fra Women's Health Initiative (WHI) en randomisert, placebokontrollert studie som skulle snu opp-ned på oppfatningen om at postmenopausal hormonsubstitusjonsbehandling (postmenopausal hormone replacement therapy, HRT) - ofte omtalt som østrogentilskudd - beskytter mot hjerteog karsykdom (2). Studien viste at risikoen for koronar hjertesykdom var nesten $30 \%$ høyere hos kvinner som fikk hormonsubstitusjonsbehandling enn hos dem som fikk placebo.

WHI-studien var ikke den første som utfordret den gamle forståelsen av østrogeners effekt på hjertet. I 1998 ble resultatene fra den randomiserte, kontrollerte HERSstudien publisert (3). Denne viste at kvinner randomisert til hormonsubstitusjonsbehandling ikke fikk mindre koronar hjertesykdom - det var snarere en tendens i retning av økt forekomst. Reaksjonen var i all hovedsak vantro verden over. For eksempel skrev Mendelsohn \& Karas året etter en oversiktsartikkel i The New England Journal of Medicine med tittelen The protective effects of estrogen on the cardiovascular system, uten å ta innover seg resultatene fra HERSstudien (4). Så, i 2002, kom altså resultatene fra WHI-studien, som konkluderte med at helserisikoen ved hormonsubstitusjon var større enn fordelene. Først da ble forbruket av slike preparater redusert kraftig.

\section{Det gamle østrogenparadigmet}

Hvorfor ble resultatene fra HERS-studien møtt med vantro? Grunnen var at en rekke observasjonelle epidemiologiske studier hadde vist at kvinner som fikk hormonsubstitusjonsbehandling, hadde færre kardiovaskulære hendelser enn dem som ikke fikk slik behandling. For eksempel sto det i en systematisk oversiktsartikkel i Annals of Internal Medicine i 1992 at hormonsubstitusjonsbehandling reduserer risikoen for hjertesykdom med $35 \%$ (5). Behandlingen var også gjenstand for omfattende markedsføring. I 1966 skrev gynekologen Rober Wilson boken Feminine forever, der han hevdet at menopausen var en sykdom som kunne forhindres ved å ta østrogener (6). Det viste seg senere at Wilson hadde sterke bindinger til farmasøytisk industri.

De første østrogenpreparatene kom på markedet allerede i 1940-årene, utvunnet fra urin fra drektige hopper. I løpet av 1970årene, da det ble klart at østrogener ga økt risiko for livmorkreft, ble progestin lagt til. I USA og Europa økte salget av slike preparater kraftig i 1980- og 1990-årene - i Norge økte bruken av østrogenholdige preparater fra ca. 30000 daglige døgndoser i 1989 til nesten 170000 i 1999 (7). Hovedindikasjonen var subjektivt plagsomme postmenopausale symptomer, men etter hvert ble det også argumentert med at østrogener var bra for hjertet. Profylakse mot hjertesykdom ble gradvis en indikasjon i seg selv.

Hvordan kunne observasjonelle studier gi et så annerledes resultat enn randomiserte, kontrollerte studier? Årsaken er antakelig det som kalles konfundering som følge av indikasjon (confounding by indication) - kvinnene som fikk hormonsubstitusjonsbehandling hadde en annen risiko for hjertesykdom enn dem som ikke fikk slik behandling. Det var rett og slett en viktig forskjell mellom kvinnene som valgte hor- monsubstitusjonsbehandling og dem som ikke valgte det. Dette er en av grunnene til at randomiserte, kontrollerte studier, der det er tilfeldig hvem som mottar intervensjonen, er mer egnet til å studere effektene av terapeutiske intervensjoner enn observasjonelle studier, der deltakerne selv velger intervensjonen.

\section{Laboratoriestudier og østrogenparadigmet}

Selv om HERS-studien ble ansett som en «anomali» i det gjeldende paradigmet om den gunstige kardiovaskulære effekten av hormonsubstitusjonsbehandling og WHIstudien langt på vei endret paradigmet til det motsatte, førte ikke dette til at alle forskere slo seg til ro med det nye paradigmet. Noe av forklaringen på dette var at multiple laboratoriestudier på cellekulturer og forsøksdyr etterlot et entydig inntrykk av at østrogener var gunstig ved kardiovaskulær sykdom.

I 2003 var jeg doktorgradsstudent og forsket på koagulasjon. Jeg skulle tilsette østrogener til endotelcellekulturer for å studere mekanismen for hvordan de reduserte koagulasjonshemmeren «tissue factor pathway inhibitor» (TFPI). Jeg visste fra epidemiologiske studier at bruk av både hormonsubstitusjon og p-piller reduserte TFPI-nivået i blodet betydelig, men jeg visste ikke hvordan. Jeg gjettet på at transkripsjonen av TFPI-genet ble nedregulert, ettersom hovedeffekten av østrogener nettopp er regulering av transkripsjonen. I de første forsøkene ble ikke resultatene som forventet, men etter enkelte justeringer av modellen og gjentatte forsøk fant jeg at TFPI-produksjonen ble redusert - uten at jeg kunne finne noen nedregulering av transkripsjonen (8). Jeg justerte altså den eksperimentelle modellen etter hva jeg forventet å finne.

I forbindelse med disse forsøkene søkte jeg etter studier der man hadde undersøkt effekten av østrogen på endotelceller og andre vaskulære celler. Etter hvert ble jeg bevisst et mønster i disse artiklene. Mønsteret var at siste setning i resymeet nesten uten unntak lød omtrent som følger: «Our results confirm the beneficial effects of estrogens on the vasculature.» 


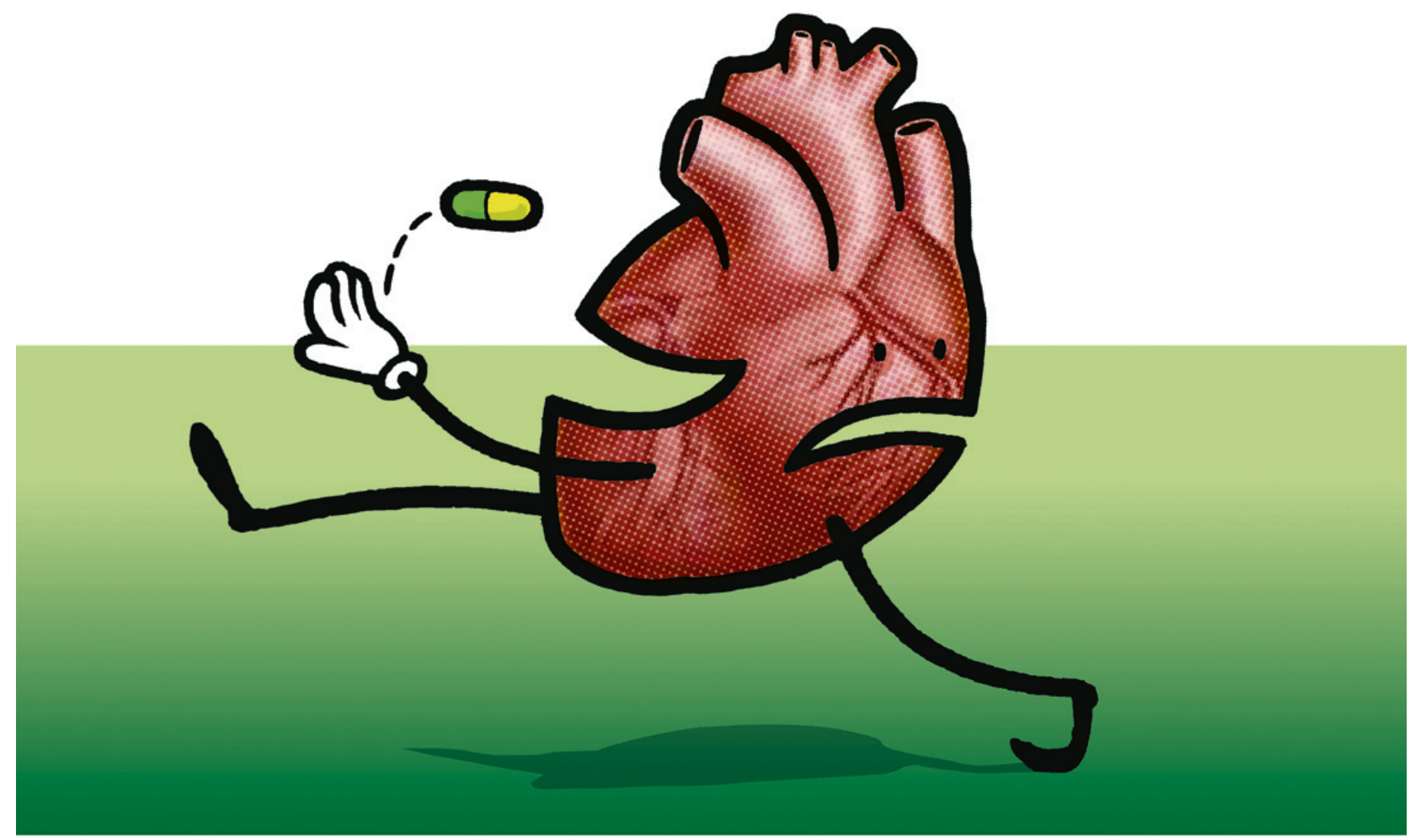

Illustrasjon $\odot$ Superpop

\section{Timinghypotesen}

Den oppsiktsvekkende store forskjellen i resultater mellom laboratoriestudier og randomiserte, kontrollerte studier av effekten av østrogen på hjerte- og karsykdom er erkjent og omtalt av flere (9). Det er dessuten lansert flere hypoteser for å forklare forskjellen, hvorav timinghypotesen er den mest kjente.

Timinghypotesen postulerer at hormonsubstitusjonsbehandling gitt rett etter menopausen er gunstig for hjertet, men at behandlingen gitt lenge etter menopausen er ugunstig. Denne hypotesen er også foreslått som forklaring på forskjellen i resultater mellom de observasjonelle og de randomiserte, kontrollerte studiene. Timinghypotesen er ennå ikke undersøkt godt nok, men den ble ikke bekreftet i reanalyser av dataene fra WHIstudien (10).

\section{Hvilke spørsmål er mulig å stille?}

En hypotese som ikke er foreslått, men som det passer å foreslå nær 50 år etter publise- ringen av Kuhns bok, er at de omtalte laboratoriestudiene ble gjort $\mathrm{i}$ en tid da alle «visste» at østrogener var bra for hjertet. Problemstillingen den gang var av typen «hva er mekanismen bak den gunstige effekten av østrogener på hjertesykdom?». Fornuftig nok, gitt kunnskapen på den tiden, men det er et element av «som man spør, får man svar». Selv forkastet jeg resultatene i mine egne forsøk da de ikke stemte med det jeg forventet - jeg trodde det var noe galt med den eksperimentelle modellen. Dette er nok en viktig grunn til at laboratorieforsøk publisert før 2003/04 først og fremst stemmer med det forrige østrogenparadigmet.

Eller sagt på en annen måte: Hvilke resultater ligger upublisert i skuffene? Det er en slående mangel på laboratoriestudier fra før 2003/04 der man stiller spørsmål ved paradigmet om at østrogener er gunstig for hjertet. Da er man igjen ved et generelt problem ved forskning, og det er at man påvirkes av hva man tror man skal finne.
$\AA$ se bort fra resultater som oppfattes som «gale» ut fra gjeldende kunnskap kan være fornuftig, men det er et metodologisk problem som sjelden diskuteres i de vitenskapelige publikasjonene.

\section{Var det gamle paradigmet riktig likevel?}

Jeg ønsker ikke å hovere over forskere som har publisert studier som støtter paradigmet om at hormonsubstitusjonsbehandling beskytter hjertet. Men forskning innebærer også å reflektere over de vitenskapelige paradigmene og hvordan disse innvirker på kunnskapsproduksjonen.

Det er nylig publisert en studie som støtter timinghypotesen (11). Kanskje var det gamle paradigmet rett likevel? Det kan være smertefullt å ta innover seg at man har gjort feil, men vi kan støtte oss til filosofen Arne Næss (1912-2009), som mente at det gjør vondt å tenke, men at dette er en smerte vi må tåle (12). 
Jeg takker Jan Frich for gjennomlesing av manuskriptet og nyttige innspill.

\section{Anders Erik Astrup Dahm (f. 1968)}

er lege i spesialisering ved Avdeling for blodsykdommer, Oslo universitetssykehus, Rikshospitalet. Han har doktorgrad innen koagulasjon og venøs trombose og forsker nå på hormoners effekt på koagulasjonen.

Forfatter har fylt ut ICMJE-skjemaet og oppgir følgende interessekonflikter: Han har mottatt foredragshonorar fra Pfizer.

\section{Litteratur}

1. Kuhn TS. The structure of scientific revolutions. Chicago: University of Chicago Press, 1962.

2. Rossouw JE, Anderson GL, Prentice RL et al. Risks and benefits of estrogen plus progestin in healthy postmenopausal women: principal results From the Women's Health Initiative randomized controlled trial. JAMA 2002; 288: 321-33.

3. Hulley S, Grady D, Bush T et al. Randomized trial of estrogen plus progestin for secondary prevention of coronary heart disease in postmenopausal women. Heart and Estrogen/progestin Replacement Study (HERS) Research Group. JAMA 1998; 280: 605-13.

4. Mendelsohn ME, Karas $\mathrm{RH}$. The protective effects of estrogen on the cardiovascular system. N Engl J Med 1999; 340: 1801-11

5. Grady D, Rubin SM, Petitti DB et al. Hormone therapy to prevent disease and prolong life in postmenopausal women. Ann Intern Med 1992; 117 : 1016-37

6. Wilson RA. Feminine forever. New York, NY M Evans Co, 1966

7. Bakken K, Eggen AE. Brukermønster for østrogen i og etter overgangsalderen i Norge. Norwegian Journal of Epidemiology 2001; 11: 81-90.

8. Dahm AE, Iversen N, Birkenes B et al. Estrogens, selective estrogen receptor modulators, and a selective estrogen receptor down-regulator inhibit endothelial production of tissue factor pathway inhibitor 1. BMC Cardiovasc Disord 2006; 6: 40

9. Kim KH, Bender JR. Rapid, estrogen receptormediated signaling: why is the endothelium so special? Sci STKE 2005; 2005: pe28.

10. Prentice RL, Manson JE, Langer RD et al. Benefits and risks of postmenopausal hormone therapy when it is initiated soon after menopause. Am J Epidemiol 2009: 170: 12-23.

11. Schierbeck LL, Rejnmark L, Tofteng CL et al. Effect of hormone replacement therapy on cardiovascular events in recently postmenopausal women: randomised trial. BMJ 2012: 345: e6409.

12. Rothenberg D. Arne Næss - gjør det vondt å tenke? Oslo: Cappelen, 2001.

Mottatt 22.1. 2013, første revisjon innsendt 19.4 2013, godkjent 2.5. 2013. Medisinsk redaktør Petter Gjersvik.

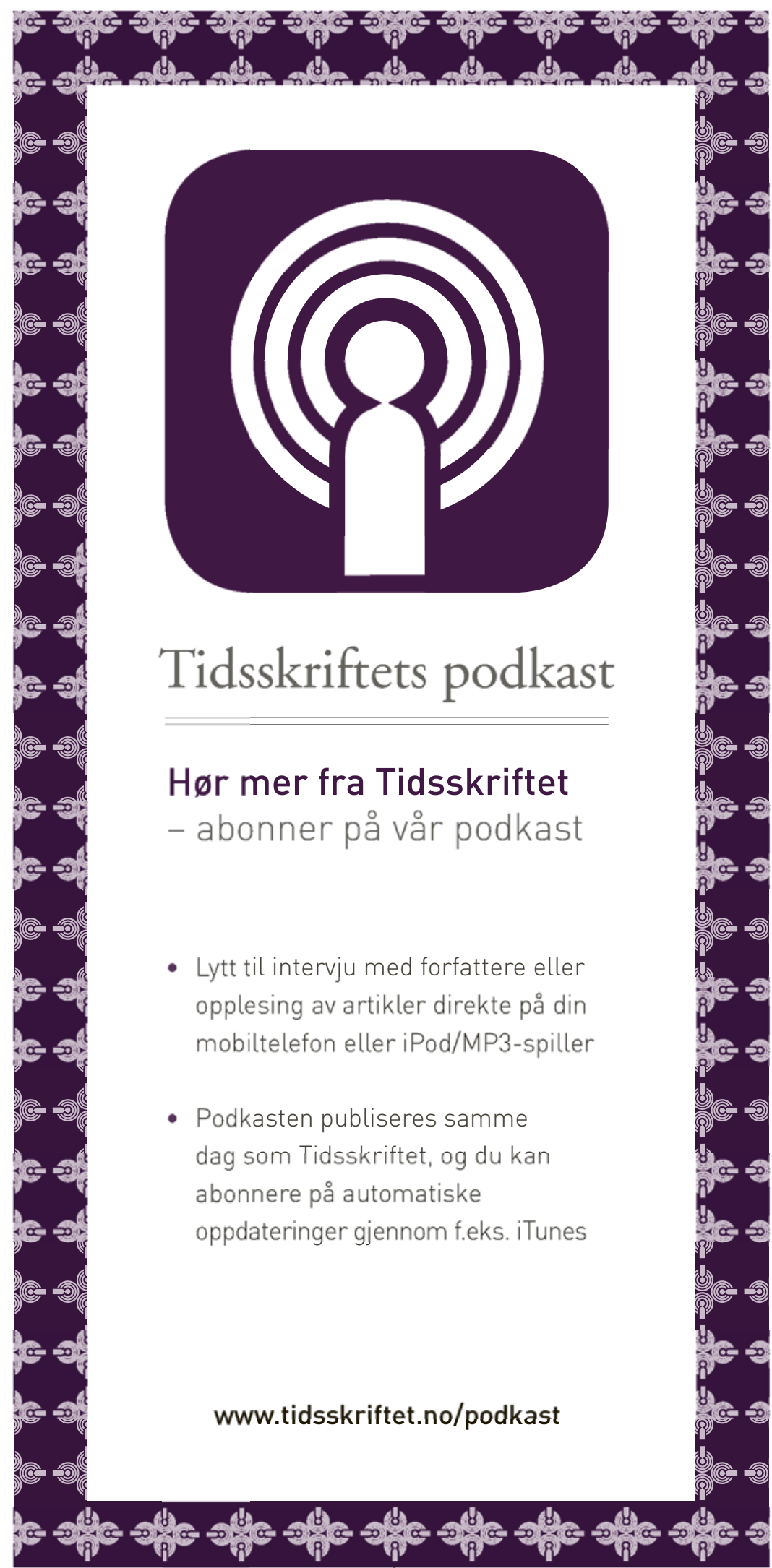

10 -

www.tidsskriftet.no 